\title{
Characteristics, Opportunities and Challenges of Goat Livestock Business Development InJeneponto RegencySouth Sulawesi Province, Indonesia
}

\author{
1Tanri Giling Rasyid, ${ }^{2}$ ST. Rohani, ${ }^{3}$ Muhammad Aminawar, ${ }^{4}$ Muhammad Darwis, ${ }^{5}$ Muhammad Erik Kurniawan \\ 1,2,3Faculty of Animal Science Hasanuddin University. \\ ${ }^{4}$ Center for Research and Development of the Dynamics of Society, Culture and Humanities Institute for Research and Community Service (LP2M) \\ Hasanuddin University Street PerintisKemerdekaan KM. 10 KampusUnhasTamalanrea, Makassar, South Sulawesi Province-Indonesia. \\ ${ }^{5}$ Program Study Animal Science STIP Muhammadiyah Sinjai, Sulawesi Selatan.
}

Correspondence Author: Tanri Giling Rasyid, Faculty of Animal Science Hasanuddin University.

E-mail: tanri.giling@gmail.com

Received date: 19 May 2018, Accepted date: 15 August 2018, Online, Online date: 20 August 2018

Copyright: (c) 2018 TanriGiling Rasyid et al. This is an open-access article distributed under the terms of the Creative Commons Attribution License, which permits unrestricted use, distribution, and reproduction in any medium, provided the original author and source are cre dited.

\begin{abstract}
In Jeneponto Regency, goat livestock is one of the regency leading commodities because it can be cultivated with economies of scale, intensive cultivation systems, natural and human resource potential and supporting local government policies.But it invites the question that why has not made a significant contribution to both farmers and regional development.This study aims to determine the characteristics, opportunities and challenges of developing goat livestock in Jeneponto Regency.The method used is descriptive research. From 11 districts in Jeneponto Regency, 3 districts were selected which had the largest goat population, Tamalatea District (34,828 tails), Bangkala Barat District $(23,274$ tails), and Bontoramba District $(20,713$ tails). Research samples from these 3 districts selected 25 people so that all of them were selected by 75 goat farmers. The sampling technique is simple random.Data collection was conducted through interviews, focus group discussions and using a Likert scale on every aspect measured, namely $1=$ low, $2=$ medium, $3=$ high and analyzed descriptively statistically.The results showed that the characteristics of goat livestock business based on forage land, farmers resources, farmers institutions, cultivation as a process subsystem, and the results of cultivation business were in the high category. Opportunities and challenges for the development of goat livestock business show a very bright prospect and have a very important role in the economic growth of the Jeneponto Regency community.
\end{abstract}

Key words: Business characteristics, opportunity, tantangan, goat livestock, farmer.

\section{INTRODUCTION}

Goats are one type of livestock that is widely cultivated by people in many developing countries including Indonesia, goats have been used as strategic commodities as an instrument of poverty alleviation and income sources[1].Aside from being a meat producer, goats also have other benefits, namely as a producer of skin, milk and feces as a high-quality organic fertilizer.Goat livestock also have its own advantages, namely in terms of maintenance which is quite simple compared to some other types of livestock.

The development of goat population through farmers empowerment is absolutely necessary, because this is important and is a challenge and opportunity for the development of livestock sub sectors, especially goats in the rural areas of Eastern Indonesia which are highly culturally diverse[2].And if this can be overcome then the poverty level can be reduced, because the utilization of natural resources can be managed optimally.

Goat livestock can be included as superior commodities in the sense that they can be pursued on an economic scale and guaranteed market potential.Thus, it can be designed a business model for developing goat farms that can favor farmers and have an impact on increasing the income and welfare of farmers.If one element of this potential is not fulfilled, it can affect other elements, and have an impact on the sustainability of the goat development effort[3].

The criteria for the development of goat livestock business set by the Regent of Jeneponto Regency is that they can contribute significantly or have high potential to goat production, facilitated by the Jeneponto Regency regional revenue and expenditure budget and supported by the South Sulawesi Province revenue and expenditure budget, and supported by the budget national income and expenditure.The decline in goat livestock population after field identification was found to indicate that the goat business development model had not run as expected or that there were still elements set forth in the general implementation guidelines[4].

From these data and descriptions, it certainly invites a question that why in Jeneponto Regency, goat livestock as one of the regency leading commodities can be cultivated with economies of scale, intensive cultivation systems, natural and human resource potential and supporting local government policies.However, it has not made a significant contribution to both farmers and regional development.

Of the problems raised, it needs attention, and is an excuse to conduct research on the potential that has been and has not been utilized to optimize empowerment of the potential of Jeneponto Regency.This is what underlies the research that aims to find out the characteristics, opportunities and challenges of business development of goats in Jeneponto Regency. 


\section{RESEARCH METHODS}

This research was carried out in April to July 2018 in Jeneponto Regency. The research method used is descriptive research. From 11 districts in Jeneponto Regency, 3 districts were selected which had the largest goat population, Tamalatea District (34,828 tails), Bangkala West District (23,274 tails), and Bontoramba District (20,713 tails)[5]. Research samples from these 3 districts selected 25 people so that all of them were selected by 75 goat farmers. The sampling technique is simple random. Data collection was conducted through interviews, focus group discussions and using a Likert scale on every aspect measured, namely $1=$ low, $2=$ medium, 3 = high and analyzed descriptively statistically[6].Characteristics of goat livestock business are measured based on forage land, goat breeders' resources, goat breeder institutions, cultivation as a process subsystem, and the results of cultivation business with class ranges are as follows:

Highest score $=$ Highest weight $\mathrm{x}$ number of respondents $\mathrm{x}$ number of questions

$$
=1125
$$
(3)
(75)
(5)

Lowest score $=$ Lowest weight $\mathrm{x}$ number of respondents $\mathrm{x}$ number of questions

(1) (75)

$$
=375
$$

Class range $=$ Highest score - Lowest score

$$
=\frac{1125-375=250}{3}
$$

From these values can be made the following categories:

High $=875-1125$

Medium $=625-875$

Low $=375-625$

\section{RESULTS AND DISCUSSION}

\section{Goat Livestock Business Characteristics:}

The results of research on the characteristics of goat business used by 75 farmers were measured based on forage land, goat farmers resources, goat farmers institutions, cultivation as a process subsystem, and the results of cultivation efforts.Based on the results of the research obtained, the institutional assessment of

\begin{tabular}{|c|c|c|c|c|c|}
\hline Number & Category & Score & $\begin{array}{l}\text { Frequency } \\
\text { (Person) }\end{array}$ & Percentage (\%) & $\begin{array}{l}\text { Value } \\
\text { (Score x Frequency) }\end{array}$ \\
\hline 1. & $\begin{array}{l}\text { Forage land } \\
\text { High } \\
\text { Medium } \\
\text { Low }\end{array}$ & $\begin{array}{l}3 \\
2 \\
1\end{array}$ & $\begin{array}{l}55 \\
12 \\
8\end{array}$ & $\begin{array}{l}73,3 \\
16 \\
10,7\end{array}$ & $\begin{array}{l}165 \\
24 \\
8\end{array}$ \\
\hline \multicolumn{2}{|l|}{ Total } & & 75 & 100 & 197 \\
\hline 2. & $\begin{array}{l}\text { Farmer resources } \\
\text { High } \\
\text { Medium } \\
\text { Low }\end{array}$ & $\begin{array}{l}3 \\
2 \\
1\end{array}$ & $\begin{array}{l}61 \\
10 \\
4\end{array}$ & $\begin{array}{l}81,3 \\
13,4 \\
5,3\end{array}$ & $\begin{array}{l}183 \\
20 \\
4\end{array}$ \\
\hline \multicolumn{2}{|l|}{ Total } & & 75 & 100 & 207 \\
\hline 3. & $\begin{array}{l}\text { Institutional Farmer } \\
\text { High } \\
\text { Medium } \\
\text { Low }\end{array}$ & $\begin{array}{l}3 \\
2 \\
1\end{array}$ & $\begin{array}{l}57 \\
11 \\
7\end{array}$ & $\begin{array}{l}76 \\
14,7 \\
9,3\end{array}$ & $\begin{array}{l}171 \\
22 \\
7\end{array}$ \\
\hline \multicolumn{2}{|l|}{ Total } & & 75 & 100 & 200 \\
\hline 4. & $\begin{array}{l}\text { Cultivation as a process subsystem } \\
\text { High } \\
\text { Medium } \\
\text { Low } \\
\end{array}$ & $\begin{array}{l}3 \\
2 \\
1 \\
\end{array}$ & $\begin{array}{l}60 \\
12 \\
3 \\
\end{array}$ & $\begin{array}{l}80 \\
16 \\
4 \\
\end{array}$ & $\begin{array}{l}180 \\
24 \\
3 \\
\end{array}$ \\
\hline \multicolumn{2}{|l|}{ Total } & & 75 & 100 & 207 \\
\hline 5. & $\begin{array}{l}\text { Cultivation results } \\
\text { High } \\
\text { Medium } \\
\text { Low }\end{array}$ & $\begin{array}{l}3 \\
2 \\
1\end{array}$ & $\begin{array}{l}63 \\
10 \\
2\end{array}$ & $\begin{array}{l}84 \\
13,3 \\
2,7\end{array}$ & $\begin{array}{l}189 \\
20 \\
2\end{array}$ \\
\hline \multicolumn{2}{|l|}{ Total } & & 75 & 100 & 211 \\
\hline \multicolumn{2}{|c|}{ Total Score } & & & & 1022 \\
\hline
\end{tabular}
goat farmers group is presented in Table 1.

Table 1: Assessment of Goat Livestock Business Characteristics.

Source: Primary Data After Processed, 2018.

Table 1 shows that the total score of the assessment of goat business characteristics of $\mathbf{1 0 2 2}$ results means that they are in the High Category (875 - 1125).

The results of the study show that based on the aspects of forage land the farmers possess can be increased through training and guidance.Land is one of the important natural resources for goat farming in each region, because it is an ecological basis for the growth of goats.Land is a place for growing forage and as a place of business activities for goats. [7]Land for livestock business is land that does not compete with food crops business. But the farmland itself has limited ability to increase forage production as animal feed because the land is poor in nutrients, especially Nitrogen, phosphorus and potassium.

The aspect of the farmers resources is based on the results of the research, an alternative solution that can increase the potential of farmers resources through training and mentoring strengthening. The approach to training goat farmers to develop goat business to achieve productive economy can be done through participatory training interventions with patterns learning by doing [3].

The results of research based on the institutional aspects of farmers can be increased through institutional strengthening by means of improving and improving the articles of association and household, critical awareness training and directing livestock farmers group.[8]In goat farming, goat farmers usually belong to group.The goal is that the goat farmers who are members of the farmer livestock group are able to cooperate with each other, and become a dynamic and developing group.The influence of the social group that were formed also differed, there were those that only affected their members, some had an effect on the surrounding community, and some also affected the survival of the people or the community, so that they were able to realize the development program.

The results of research based on aspects of goat farming carried out by farmers can be improved, of course through training, and briefing on the guidance of farmers which then the results of the training and direction of researchers are expected to be transmitted to other farmers. The goat farmers system is divided into 
Citation: TanriGiling Rasyid, 2018. Characteristics, Opportunities and Challenges of Goat Livestock Business Development InJeneponto RegencySouth Sulawesi Province, Indonesia. Advances in Environmental Biology., 12(8): 7-9. DOI: 10.22587/aeb.2018.12.8.2

three systems, namely (a) intensive systems, (b) semi intensive systems and (c) extensive systems. The three systems for raising goats are used depending on the designation, whether for a part time business or a principal business.For part time businesses, most farmers use grazing or extensive systems, while for goat farmers whose purpose is for basic business such as fattening, while breeding and dairy business, the system used is intensive or semi intensive[9].

Aspects of the results of goat farming based on the results of the study indicate that the results of goat farming can be sold smoothly because every time the goat market is always available. [9] Goats have long been cultivated by people in Indonesia as part time businesses or savings because the maintenance and marketing of their products is relatively easy. Production produced from goat livestock, namely meat, milk, skin, fur and dirt as fertilizer is very useful.

Opportunities and Challenges for Goat Livestock Business Development:

The current goat business development shows a very bright prospect and has a very important role in the economic growth of the community. Most people recognize that goat livestock play a very important role in the future.

The results of the study can be identified goat business development opportunities in Jeneponto Regency are: (a) demand for meat continues to increase, (b) the existence of cooperation between regions and universities, (c) the availability of technology from existing research institutions such as universities, BPTP, LIPI, Veterinary Center and others,(d) At present national development is beginning to move towards the Eastern Region of Indonesia. The logicalconse quince of this is the increasing number of people who are interested and doing economic activities in Eastern Region of Indonesia. Increased economic activity in Eastern Region of Indonesia, especially in South Sulawesi Province and Makassar City as gateways and living rooms for Eastern Region of Indonesia communities, can créate various market opportunities for Jeneponto Regency resources, and (e) the Government of the Republic of Indonesia has a commitment to accelerate development in Eastern Region of Indonesia. The Government's commitmentisrealized through the development of various programs for Eastern Region of Indonesia. Thisprogram can accelerateeconomicgrowthforvariousregions in Eastern Region of Indonesia including in Jeneponto Regency. [10] The potential of livestock business processing can be started in the development of cultivation by utilizing the extent of land that can be used as a ranch. In addition to cultivation, another business is fattening.

The challenges of business development of goats in Jeneponto Regency which can be identified are: (a) the control of the trade chain of goats is still long, (b) the business climate is not conducive, (c) law enforcement is still weak, (d) one of the characteristics of livestock commodities including livestock goats are price instability,(e) the knowledge and ability of farmers in adopting farmers technology is still low, (f) the threat of a decline in livestock populations and increased expenditure of livestock outside the regency, $(\mathrm{g})$ the high price of meat on the market, $(\mathrm{h})$ emergence of emergency diseases such as anthrax, cow snoring (Septicemia epizootica) dairy cows (brucellosis), bird flu (Avian Influenza), (i) awareness of the perpetrators of trade traffic regulations cattle are still low,(j) the low processing technology and marketing of livestock products in rural areas, $(\mathrm{k})$ the low exchange rate of farmers production results, resulting in lower bargaining position of farmers, (1) limited financing schemes and ability to access financing institutions, (m) farmers patterns of management of livestock business is still traditional, (n) weak quality of human resources both skills, mastery of technology, and professionalism and entrepreneurship, and (o) not yet creating synergy across sectors and regions. Local resources have also not been connected across regions in the form of cooperation between regions.

Based on the challenges faced, the development of goat livestock business requires a new paradigm that focuses on the realization of a healthy, productive and local resource based society. [11]Paradigm farm development was the realization of a healthy society and productive and creative through a tough farm based on local resources To achieve this paradigm performed a variety of missions, namely: (a) provide food from cattle, (b) empower human resource farms, (c) increase the income of farmers, (d) create jobs livestock, and (e) to preserve and utilize natural resources, which as a whole in line with agricultural development programs that build food security and developing the agribusiness sector.

[12]Recently, the demand for beef has increased dramatically. This has happened because there has been an increase in both the population and in the per capita income in Indonesia. The existing beef supply is not enough to fulfill the demand for beef. Therefore, livestock development is directed at improving the quantity and quality of beef production, increasing revenue, expanding employment and providing opportunities for rural communities. Ranch farming requires hard work, perseverance, and the strong will of farmers to reach their goals.

\section{CONCLUSIONS:}

From the results and discussion, it can be concluded that the characteristics of goat livestock business based on forage land, farmers resources, farmers institutions, cultivation as a process subsystem, and the results of aquaculture are in the high categ ory. Opportunities and challenges for the development of goat livestock business show a very bright prospect and have a very important role in the economic growth of the Jeneponto Regency community.

\section{REFERENCES}

[1] Rasyid, T.G., S. Hasan, S. Rasjid, S.N. Sirajuddin, 2015. Accessibility goat livestock cooperation with the government, merchant banking and collecting in Majene regency, West Sulawesi Province. American-Eurasian Journal of Sustainable Agriculture, 9(7): 13-19.

[2] Sasongko, W.R., Y.G. Bulu and A. Surahman, 2012. Marginal Dry Land Utilization through Integration of Food Crops, Feed Plants, and Ruminants.Feed and Pasture Cultivation Papers.Gadjah Mada University. Yogyakarta.

[3] Rasyid, T.G., S. Hasan, S. Rasjid, S.N. Sirajuddin, 2016. Development model of goat farming business base on productive economy in Majene regency, West Sulawesi, Indonesia. American-Eurasian Journal of Sustainable Agriculture, 10(3): 1-6.

[4] Rasyid, T.G., S.T. Rohani, M. Aminawar, 2017. Strengthening of Social Capital Institution and Its Impact on Development of Goat Based Livestock Economy Based Business in Jeneponto Regency of South Sulawesi Province. First Year Report on Superior Research of Higher Education. Institute for Research and Community Service Hasanuddin University, Makassar.

[5] Jeneponto Regency Central Statistics Agency, 2017. Jeneponto Regency In Year Figures 2017. Office of the Central Statistics Agency of Jeneponto Regency, Jeneponto.

[6] Sugiyono, 2011. Quantitative Research Methods, Qualitative and R \& D. Alfabeta, Bandung.

[7] Hasan, S., 2012. Dry/Critical Land Empowerment Through Integration of Ruminant Forage and Livestock Feed. Faculty of Animal Science, Hasanuddin University, Makassar.

[8] Rasyid, T.G., Rohani, M. Aminawar and M. Darwis, 2018. The Level of Social Capital and its Effect on the Participation of Farmers on Goat Livestock Business Development in Jeneponto Regency South Sulawesi Provinsi-Indonesia. Advances in Environmental Biology., 12(2): 13.DOI:10.22587/aeb.2018.12.2.1.http://www.aensiweb.net/AENSIWEB/aeb/aeb/2018/February/1-3(1).pdf

[9] Rasyid, T.G., 2016. Alternative Model of Goat Based Livestock Development Based on Socio Economic in Majene District, West Sulawesi Province. Postgraduate Program of Hasanuddin University. Dissertation, Makassar.

[10] Sudirman, I., M. Nohong, M. Darwis, M.E. Erik, W. Hidayat, B. Irawan and Rahmawati, 2018. Study of Local Revenue Sources in North Luwu Regency South Sulawesi Province-Indonesia. $\quad$ Advances in $\quad$ Environmental $\quad$ Biology., $\quad 12(2)$ : 4-7.DOI: 10.22587/aeb.2018.12.2.2.http://www.aensiweb.net/AENSIWEB/aeb/aeb/2018/February/4-7(2).pdf

[11] Sirajuddin, S.N., M.E. Kurniawan, 2016. Level technology adoption and characteristic cattle breeders who following Bachelor Village Building. AmericanEurasian Journal of Sustainable Agriculture, 10(5): 28-33.

[12] Sirajuddin, S.N., S. Nurlaelah, A. Amrawaty, T. Amrullah, S. Rohani, I.M. Saleh, 2017. RelationshipBetween Farmers Characteristic and Income from Beef Cattle with The Traditional Profit-Sharing. American-Eurasian Journal of Sustainability Agriculture, 11(5): 29-34. 